\title{
PENGARUH E-WOM DI MEDIA SOSIAL YOUTUBE TERHADAP PURCHASE INTENTION (MINAT BELI) PADA BRAND SMARTPHONE SAMSUNG
}

\section{Ketut Dewi Kurnia Sari ${ }^{1}$ Osa Omar Sharif ${ }^{2}$}

\section{Article history:}

Submitted: 10 Mei 2021

Revised: 28 Juli 2021

Accepted: 31 Agustus 2021

\section{Keywords:}

E-Wom;

Brand Attitude;

Purchase intention;

Structural Equation Modeling; AMOS;

\section{Kata Kunci:}

E-Wom;

Brand Attitude;

Purchase intention;

Structural Equation Modeling; AMOS;

\section{Koresponding:}

Fakultas Ekonomi dan Bisnis Universitas Telkom Bandung Email: dewikurnia1102@gmail.com
Abstract

This study aims to determine how the influence of Electronic Word of Mouth (eWOM) on Youtube social media on Purchase intention on Samsung smartphones in Bandung with the presence of a mediator from Brand Attitude. The research method used is a quantitative method with the aim of research being descriptive, the type of research is causal, the data collection technique used in this study is non-probability sampling, and the data collection method is cross sectional. In this study the population used in this study were smartphone users in Bandung. The population in this study are smartphone users in Bandung who use social media Youtube. The sampling technique uses the Cochran formula so that a minimum sample size of 385 respondents is determined and the valid respondent research is 400 respondents. The data analysis technique is a multivariate technique through the Structural Equation Modeling (SEM) method. For data analysis using the AMOS 24 application. The findings from this study indicate that there is an effect of eWOM on Brand Attitude, eWOM has no effect on purchase intention, brand attitude has a significant effect on purchase intention and Brand attitude mediates eWOM on purchase intention of Samsung brand smartphones on social media Youtube. .

Abstrak
Penelitian ini bertujuan untuk mengetahui bagaimana pengaruh
Electronic Word of Mouth (eWOM) di media sosial Youtube terhadap
Purchase intention pada smartphone Samsung di Bandung dengan adanya
mediator dari Brand Attitude. Metode penelitian yang digunakan adalah
metode kuantitatif dengan tujuan penelitian bersifat deskriptif, tipe
penelitian bersifat kausal, teknik pengumpulan data yang digunakan pada
penelitian ini adalah non-probability sampling, metode pengumpulan data
dengan cross sectional. Pada penelitian ini populasi yang digunakan pada
penelitian ini adalah pengguna smartphone di Bandung. Populasi dalam
penelitian ini adalah pengguna smartphone di Bandung yang menggunakan
media sosial Youtube.Teknik pengambil sampel menggunakan Rumus
Cochran sehingga ditentukan jumlah sampel minimal 385 responden dan
pada penelitian responden yang valid yaitu sebanyak 400 responden. Teknik
analisis data adalah teknik multivariat melalui metode Structural Equation
Modeling (SEM). Untuk analisis data menggunakan aplikasi AMOS 24.
Hasil temuan dari penelitian ini menunjukkan adanya pengaruh eWOM
terhadap Brand Attitude, eWOM tidak berpengaruh terhadap Purchase
intention, brand attitude berbengaruh signifikan terhadap purchase intention
dan Brand attitude memdiasi eWOM terhadap purchase intention
martphone brand Samsung di media sosial Youtube.

Fakultas Ekonomi dan Bisnis Universitas Telkom Bandung, Jawa Barat ${ }^{1,2}$

Email: dewikurnia1102@gmail.com 


\section{PENDAHULUAN}

Samsung memiliki kesuksesan bisnis yang dijalani yaitu dalam industry elektronik, Samsung telah diakui secara global sebagai pimpinan dalam teknologi dan kini termasuk dalam 10 merek teratas global (Samsung, 2020a). PT. Samsung Electronics Indonesia adalah perusahaan manufaktur elektronik asal Korea Selatan yang telah berdiri selama 25 tahun di Indonesia. Samsung saat ini berada dalam masa kejayaannya dan merajai pasar smartphone dunia. Perusahaan Samsung memiliki lima core value yang menjadi kunci sukses perjalan panjang kami dari masa ke masa yaitu People, Excellence, Change, Integrity, dan Co-Prosperity. Dengan perusahaan berstandar internasional dan mengedepankan kepatuhan terhadap hukum yang berlaku, mampu menjamin kesejahteraan karyawan yang menjadi aset utama, menciptakan lingkungan kerja yang baik dengan moto Great Work Place, dan mengedepankan keseimbangan hidup karyawannya dengan moto Work Life Balance.

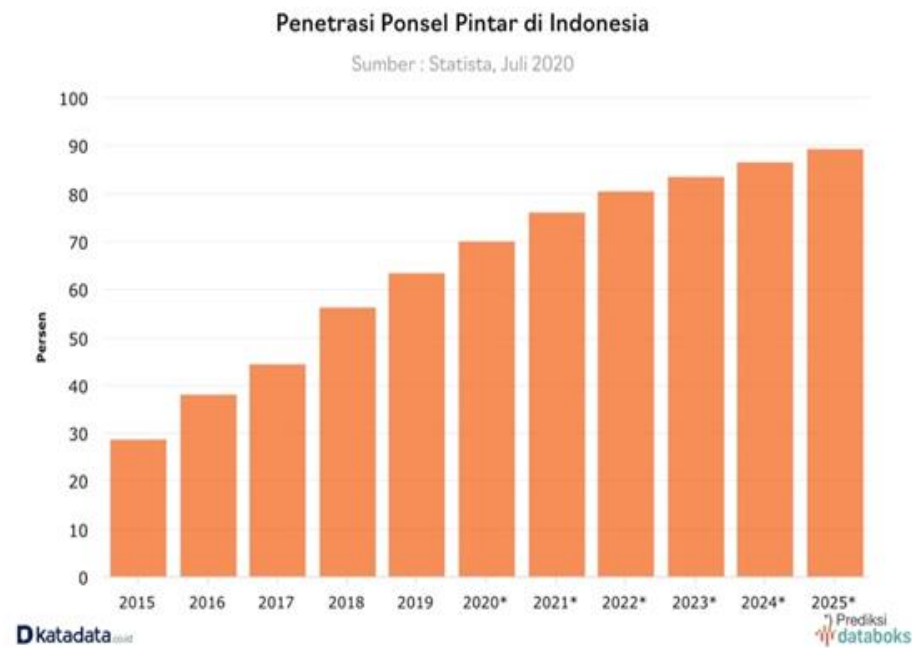

Gambar 1.

Pengguna Smartphone di Indonesia terus Meningkat Sampai tahun 2025

Sumber: Pusparisa (2020)

Pada Gambar 1, dijelaskan bahwa lebih dari setengah populasi di Indonesia atau 56,2\% telah menggunakan smartphone pada 2018. Setahun setelahnya, sebanyak 63,3\% masyarakat menggunakan smartphone. Hingga 2025, setidaknya $89,2 \%$ populasi di Indonesia telah memanfaatkan smartphone Dalam kurun waktu enam tahun sejak 2019, penetrasi smartphone di tanah air tumbuh 25,9\% (Pusparisa, 2020). Dalam penelitian yang dilakukan oleh Pusparisa (2019) mengatakan bahwa dari berbagai merek smartphone yang ada, Samsung masih bertahan sebagai pemimpin pasar smartphone global.

Tabel 1.

Top Brand Award kategori Smartphone

\begin{tabular}{cll}
\hline No & Brand smartphone & Jumlah $\%$ \\
\hline 1 & Samsung & $46.5 \%$ \\
2 & Oppo & $17.7 \%$ \\
3 & Xiaomi & $10.1 \%$ \\
4 & Vivo & $7.9 \%$ \\
5 & Lenovo & $2.0 \%$ \\
\hline
\end{tabular}

Sumber: Top Brand Award, 2020

Berdasarkan Tabel 1, menyatakan bahwa menurut Top Brand Award kategori smartphone yang menduduki peringkat satu yaitu Samsung dengan persentase sebesar 46.5\%, untuk peringkat dua yaitu Oppo dengan persentase sebesar $17.7 \%$, lalu di peringkat tiga ada Xiomi dengan persentase Pengaruh E-WOM di Media Sosial Youtube Terhadap Purchase Intention (Minat Beli) Pada Brand Smartphone 
sebesar $10.1 \%$, diikuti peringkat empat ada Vivo dengan persentase $7.9 \%$ dan peringkat lima ada Lenovo dengan persentase $2.0 \%$.

Walaupun Samsung masih menjadi pemimpin pasar penjualan smartphone, namun pangsa pasar yang diperoleh Samsung mengalami penurunan, selaras dengan penurunan pasar smartphone global (Anggraeni, 2020). Samsung yang hanya menjual sekitar 55 juta unit pada kuartal kedua, turun $27,1 \%$ secara year over year (Dwinanda, 2020).

Indonesia Top 5 Smartphone Companies, 2020Q1 Unit Market Share

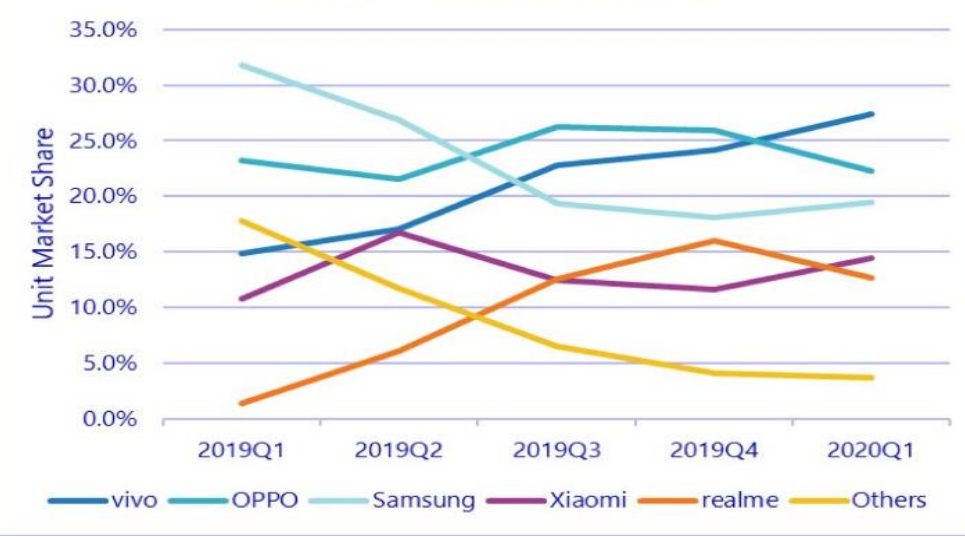

Gambar 2.

Top 5 Smartphone Companies 2020 Q1 Unit Market Share

Sumber: International Data Corporation (2020)

Pada Gambar 2, Samsung mengalami penurunan market share di Quartal 1. Vivo dengan market share tertinggi untuk pertama kalinya pada tahun 2020 di Quartal 1 lalu diikuti Oppo, Samsung, Xiaomi, dan Realme mengekor di belakangnya dalam daftar lima besar penguasa pasar smartphone di Indonesia pada Quartal 1 di tahun 2020 (International Data Corporation, 2020). Pada Gambar 3, dikatakan bahwa pada kuartal II-2020 Samsung menjual 54,76 juta ponsel atau anjlok $27,1 \%$ dari periode yang sama tahun sebelumnya. Lalu diikuti oleh brand Huawei, Apple, Xiaomi, Oppo dan yang lainnya. Menurut Wardani (2020) Samsung mengalami penurunan paling parah dalam hal penjualan di Quartal kedua. Penjualan smartphone Samsung turun sekitar 27,4 persen. Salah satu alasan menurunnya penjualan smartphone Samsung karena kepercayaan konsumen yang menurun dan khawatir akan banyaknya penipuan yang mengatasnamakan Samsung, sehingga berakibat merugikan konsumen (Wahdian, 2020).

\begin{tabular}{|c|c|c|c|c|c|}
\hline \multirow[t]{2}{*}{ Vendor } & \multicolumn{2}{|c|}{ 2Q202Q20 Market } & \multicolumn{2}{|c|}{$2 Q 192 Q 19$ Market } & \multirow{2}{*}{$\begin{array}{r}2 Q 20-2 Q 19 \\
\text { Growth (\%) }\end{array}$} \\
\hline & Units & lare (\%) & Units & Share (\%) & \\
\hline Samsung & 54.759 .4 & 18.6 & $75,111.8$ & 20.3 & -27.1 \\
\hline Huawei & $54,125.0$ & 18.4 & $58,055.7$ & 15.7 & -6.8 \\
\hline Apple & $38,386.1$ & 13.0 & $38,522.9$ & 10.4 & -0.4 \\
\hline Xiaomi & 26.095 .2 & 8.9 & $33,250.7$ & 9.0 & -21.5 \\
\hline OPPO & $23,612.1$ & 8.0 & $28,070.2$ & 7.6 & -15.9 \\
\hline Others & $97,692.1$ & 33.2 & $137,282.5$ & 37.1 & -28.8 \\
\hline Total & $294,669.9$ & 100.0 & $370,293.9$ & 100.0 & -20.4 \\
\hline
\end{tabular}

Due to rounding, some figures may not add up precisely to the totals shown.

\section{Gambar 3.}

Lima Penjualan Smartphone dari Vendor pada Quartal Kedua tahun 2020

Sumber: Franedya (2020)

Pengaruh E-WOM di Media Sosial Youtube Terhadap Purchase Intention (Minat Beli) Pada Brand Smartphone Samsung, 
Banyaknya jenis dan merek smartphone yang ditawarkan di pasar membuat konsumen memiliki banyak pilihan dan hal ini sangat mendorong para produsen untuk menjual produknya dengan kualitas yang baik dan harga yang kompetitif (Billfakkar \& Widyastuti, 2016). Untuk itu, salah satu cara untuk mengatasi hal tersebut adalah dengan melakukan pencarian referensi terhadap suatu produk tertentu. Konsumen cenderung mengandalkan ulasan online untuk membeli barang elektronik (Jung \& Kim, 2012). Salah satu aspek online yang dapat dimaksimalkan oleh suatu perusahaan sebagai media untuk membantu aktifitas pemasaran mereka yaitu media sosial. Media sosial dapat mendorong suatu perusahaan untuk berbagi informasi secara lebih terbuka dengan konsumennya. Media sosial sangat hemat dalam pengeluaran biaya dan merupakan pilihan yang tepat untuk mengakses dan mengumpulkan informasi dari konsumen lain. Media sosial juga dapat mempengaruhi keputusan pelanggan untuk membeli produk perusahaan dan mendorong pelanggan untuk saling berbicara tentang produk dan layanan perusahaan (Abzari et al., 2014).

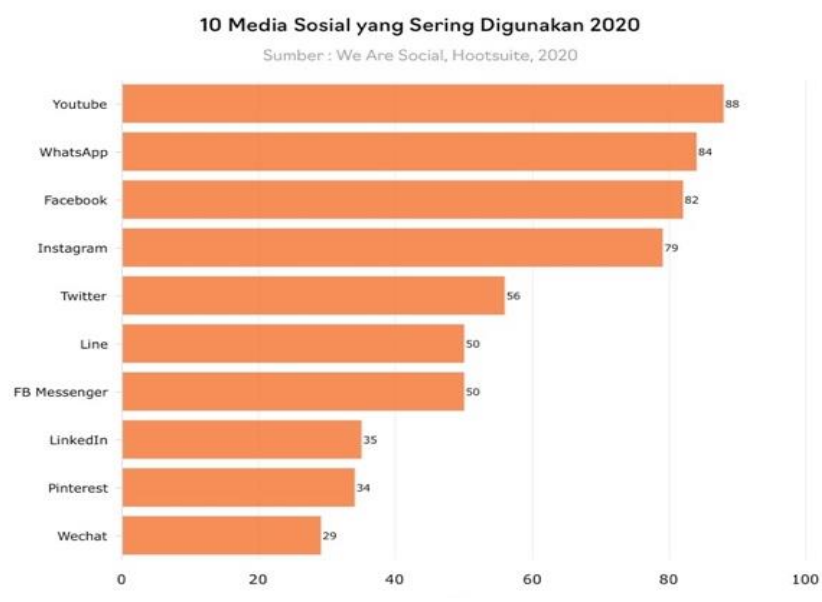

Gambar 4.

Sumber: Jayani (2020)

\section{Media Sosial yang Sering Digunakan di Indonesia 2020}

Pada Gambar 4, dijelaskan bahwa Youtube merupakan salah satu platform yang sering digunakan pengguna media sosial di Indonesia yang berusia 16 hingga 64 tahun. Persentase pengguna yang mengakses Youtube mencapai 88\%. Di media sosial seperti Youtube, banyak konsumen yang mengulas berbagai macam hal tentang gadget, baik itu smartphone, kamera, aksesories, PC/Laptop dan sebagainya (Pradipta, 2017). Sebanyak 19\% pengguna Youtube menggunakannya sebagai pertimbangan ketika ragu untuk membeli barang. Jumlah persentase yang sama juga menelusuri konten-konten video untuk mencari tahu perkembangan dunia (Jayani, 2020). Youtube lebih efektif dalam memengaruhi sikap penonton terhadap suatu produk atau layanan (Khalisha et al., 2019). Menurut Gruen et al., (2006) mengartikan eWOM sebagai sebuah media komunikasi untuk saling berbagi informasi mengenai suatu poduk atau jasa yang telah dikonsumsi antar konsumen yang tidak saling mengenal dan bertemu sebelumnya. eWOM juga harus di imbangi dengan brand attitude yang positif, menurut Keller \&Lehmann (2006) jika konsumen memiliki brand attitude positif untuk sebuah merek, akan berdampak signifikan untuk tujuan membeli dan kesiapan untuk membayar.

Promosi konsumen Samsung yang dirasakan melalui Youtube sebanyak 73,3\% atau termasuk dalam kategori baik, hal ini dikarenakan pesan promosi yang disampaikan Samsung di media Youtube terlihat jelas baik suara maupun gambar dan kapanpun kita mau dapat melihat kembali iklan tersebut di akun Youtube Samsung, berbeda dengan media lain yang mengandalkan kapasitas memori pengguna harus mengunduh terlebih dahulu jika ingin melihat iklan video khususnya berbasis Samsung, hal ini memberikan kesan yang positif bagi konsumen. Selain itu, konten Samsung yang muncul di media sosial Youtube mampu mempengaruhi persepsi konsumen (Harrie et al., 2017). Review Produk dari Konsumen terdapat pada Kolom Komentar Review Produk dari Konsumen

Pengaruh E-WOM di Media Sosial Youtube Terhadap Purchase Intention (Minat Beli) Pada Brand Smartphone 
terdapat pada Kolom Komentar diperlihatkan ada beberapa ulasan dari konsumen smartphone Samsung dari berbagai jenis produk Samsung dan ada yang merasa kecewa dengan performa smartphone yang dimiliki smartphone Samsung bahkan merasakan sebaliknya.

Menurut Jalilvand \& Samiei (2012) mengatakan adanya rekomendasi ataupun ulasan yang diberikan konsumen lain misal dalam sebuah sharing review platform ataupun komunitas akan mampu mempengaruhi minat beli konsumen. Pernyataan ini juga didukung bahwa yang mengindikasikan electronic word of mouth dapat memiliki dampak pada purchase intention jika melalui sikap konsumen (Jalilvand et al., 2012). Sikap terhadap sesuatu adalah anteseden niat, tetapi juga sejauh mana seseorang memiliki evaluasi atau penghargaan perilaku yang menguntungkan atau tidak menguntungkan terhadap situasi pembelian apa pun. Niat pembelian merupakan salah satu faktor yang penting di dalam bidang pemasaran, karena niat pembelian akan menjadi dasar dalam suatu keputusan pembelian (Toufani, 2015). Dengan eWOM yang dilakukan perusahaan Samsung maupun eWOM yang diberikan konsumen Samsung secara langsung, penulis tertarik melakukan penelitian apakah eWOM yang tersedia pada media sosial Youtube untuk smartphone Samsung akan membantu konsumen untuk melakukan sebuah pembelian pada smartphone Samsung atau memang karna sikap konsumen terhadap merek Samsung dengan judul "Pengaruh eWOM di media sosial Youtube terhadap purchase intention pada smartphone Samsung di Bandung".

Menurut Wahdian (2020) salah satu alasan menurunnya penjualan smartphone Samsung karena kepercayaan konsumen yang menurun dan khawatir akan banyaknya penipuan yang mengatasnamakan Samsung, sehingga berakibat merugikan konsumen. Untuk itu, salah satu cara untuk mengatasi hal tersebut adalah dengan melakukan pencarian referensi terhadap suatu produk tertentu. Konsumen cenderung mengandalkan ulasan online untuk membeli barang elektronik (Jung \& Kim, 2012). Youtube merupakan salah satu platform yang sering digunakan untuk mengulas berbagai macam hal tentang gadget, baik itu smartphone, kamera, aksesories, PC/Laptop dan sebagainya (Pradipta, 2017). EWOM sebagai sebuah media komunikasi untuk saling berbagi informasi mengenai suatu poduk atau jasa yang telah dikonsumsi antar konsumen yang tidak saling mengenal dan bertemu sebelumnya. EWOM juga harus diimbangi dengan brand attitude yang positif, menurut Keller \& Lehmann (2006) jika konsumen memiliki brand attitude positive untuk sebuah merek, akan berdampak signifikan untuk tujuan membeli dan kesiapan untuk membayar. Oleh karena itu penelitian ini digunakan untuk mengetahui pengaruh eWOM di media sosial Youtube terhadap purchase intention dengan adanya variabel brand attitude sebagai variable intervening pada smartphone Samsung di Bandung.

Menurut Kotler \& Keller (2012) bauran komunikasi pemasaran merupakan penggabungan dari beberapa model komunikasi pemasaran. Menurut Kotler \& Keller (2012) konsumen berbicara tentang merekatau produk di media sosial dan produk hiburan (seperti film, acara TV, dan publikasi dalam makanan, layanan perjalanan, dan toko ritel) dari mulut ke mulut setiap hari. (Ismagilova et al., 2017) menjelaskan dalam literatur pemasaran dan komunikasi, ini hanya mengacu pada komunikasi antarpribadi tentang badan usaha. (Ismagilova et al., 2017) dikatakan eWOM adalah proses pertukaran informasi yang dinamis dan berkelanjutan antara calon konsumen, konsumen saat ini dan mantan konsumen tentang suatu produk, layanan, merek atau perusahaan, yang dapat diakses oleh banyak orang dan institusi melalui Internet. Definisi ini menekankan bahwa komunikasi eWOM bukanlah proses statis, tetapi pertukaran informasi yang dinamis dan terus menerus, karena pesan dapat menyebar secara online secara spontan. Selain itu, definisi ini menentukan konten dan Sumber rekomendasi ini dan fakta bahwa rekomendasi tersebut muncul secara online. EWOM dapat digambarkan sebagai cara komunikasi yang memberikan informasi kepada konsumen tentang penjual dan penggunaan produk dan layanan melalui teknologi berbasis internet. Menurut (Hennig-Thurau, 2014) eWOM dapat didefinisikan sebagai pernyataan positif atau negatif yang dibuat oleh pelanggan potensial, saat ini atau sebelumnya tentang suatu produk atau perusahaan yang tersedia untuk banyak orang dan institusi melalui Internet. EWOM juga difasilitasi dalam berbagai jenis platform yang mengkomunikasikan opini dan bertukar informasi produk, yang tersedia untuk sebagian besar orang dan pemasar dalam organisasi (Hennig-Thurau, 2014). Mengingat kemudahan Internet memberikan banyak peluang bagi konsumen yang mengandalkan eWOM. Konsumen tersebut dapat memperoleh informasi dari konsumen lain untuk membentuk opini tentang barang dan jasa (Sparks \& Browning,

Pengaruh E-WOM di Media Sosial Youtube Terhadap Purchase Intention (Minat Beli) Pada Brand Smartphone Samsung, 
n.d.). Selain itu, eWOM memungkinkan konsumen mengurangi waktu dan tenaga yang dibutuhkan untuk memperoleh informasi produk atau layanan tertentu (Goldsmith \& Horowitz, 2006).

Dalam model ekuitas merek diketahui bahwa Ketika brand attitude semakin positif maka pangsa pasar akan meningkat. Sikap merek didefinisikan, berdasarkan Mitchell \& Olson (1981), sebagai sikap positif atau negatif konsumen terhadap suatu merek. Sikap merek adalah pengakuan pribadi dan aspek emosional dari merek biro iklan. Sikap terhadap merek berguna dalam memprediksi perilaku konsumen. Dengan demikian, di mana bentuk sikap merek dan bagaimana hal itu dapat mempengaruhi hasil perilaku penting telah diperiksa secara mendalam (Olsen et al., 2014).

Purchase intention atau minat beli menurut Kotler \& Keller (2012), minat beli konsumen adalah suatu perilaku konsumen, menurut pengalaman memilih, menggunakan, mengkonsumsi atau bahkan menginginkan suatu produk, konsumen ingin membeli atau memilih suatu produk. Niat membeli telah dianggap sebagai salah satu elemen penting dari perilaku pembelian konsumen, karena mempengaruhi konsumen dalam memilih merek tertentu di antara beberapa merek di pasar (Spears \& Singh, 2004). (Appel et al., 2020) mengatakan bahwa media sosial merupakan kumpulan teknologi digital berbasis perangkat lunak biasanya disajikan sebagai aplikasi dan situs web yang menyediakan lingkungan digital bagi pengguna tempat mereka dapat mengirim dan menerima konten atau informasi digital melalui beberapa jenis jaringan sosial daring. Media sosial telah menjadi segalanya secara virtual - konten, informasi, perilaku, orang, organisasi, institusi - yang dapat ada dalam lingkungan digital jaringan yang saling berhubungan di mana interaktivitas dimungkinkan (Appel et al., 2020).

Setiap situs jejaring sosial memiliki karakteristik berbeda dengan khalayak yang berbeda. Bisnis di media sosial tidak hanya sebatas Facebook, mereka juga sangat hadir di Twitter, Youtube dan platform lainnya (Kumar, 2017). eWOM adalah proses pertukaran informasi yang dinamis dan berkelanjutan antara calon konsumen, konsumen saat ini dan mantan konsumen tentang suatu produk, layanan, merek atau perusahaan, yang dapat diakses oleh banyak orang dan institusi melalui internet (Ismagilova et al., 2017). EWOM juga harus di imbangi dengan brand attitude yang positif, menurut Keller \& Lehmann (2006) jika konsumen memiliki brand attitude positive untuk sebuah merek, akan berdampak signifikan untuk tujuan membeli dan kesiapan untuk membayar. Pada penelitian yang dilakukan oleh (Heryana \& Yasa, 2020) electronic word of mouth berpengaruh terhadap brand attitude karena semakin banyak review word of mouth secara online atau elektronik pada akun media sosial untuk bisnis maka semakin kuat atau meningkatkan brand attitude pembeli atau pengguna merek tersebut.

H1: $e W O M$ berpengaruh positif signifikan terhadap brand attitude

Imbayani \& Gama (2018) mengatakan bahwa review yang lebih baik dari seseorang dari internet menghasilkan minat beli yang tinggi. Hasil penelitian menunjukkan bahwa dalam konteks pemasaran mikroblogging, eWOM yang memiliki lebih banyak komentar dan penerusan memiliki pengaruh yang lebih besar terhadap niat beli konsumen. Ketika eWOM memiliki komentar objektif dan faktual, itu memiliki pengaruh yang lebih besar pada niat beli konsumen dan Ketika eWOM dengan komentar negatif memiliki pengaruh yang lebih besar terhadap keputusan pembelian konsumen. Dengan tercipta eWom yang tinggi, dan berpengaruh pada minat beli konsumen maka dapat memprediksi sales dimasa depan (Ismagilova et al., 2017).

H2: $e W O M$ berpengaruh positif signifikan terhadap purchase intention

Sikap terhadap merek berguna dalam memprediksi perilaku konsumen (Olsen et al., 2014). Sikap konsumen terhadap merek memiliki pengaruh penting terhadap niat beli, karena sikap merek merupakan determinan terpenting dari niat beli (Abzari \& Vosta, 2014). Jika sikap merek konsumen menghasilkan evaluasi merek yang baik maka akan mempengaruhi sikap dan perilaku konsumen terhadap niat membeli produk. Jika konsumen memiliki sikap merek yang positif terhadap merek maka akan berdampak signifikan terhadap tujuan pembelian dan kemauan untuk membayar (Keller \& Lehmann, 2006). Sikap merek memiliki pengaruh yang lebih besar terhadap niat beli daripada sikap periklanan. (Lee et al., 2017)

H3: Brand attitude berpengaruh positif dengan terhadap purchase intention

Tan \& Keni, (2020) menyatakan bahwa brand attitude dapat memediasi pengaruh purchase intention. Prendergast et al., (2010), menyatakan sikap positif pembeli terhadap informasi E-WOM dalam forum online akan memperkuat nilai pembelian. Menurut penelitian Erkan \& Evans, (2016)

Pengaruh E-WOM di Media Sosial Youtube Terhadap Purchase Intention (Minat Beli) Pada Brand Smartphone Samsung, 
menunjukkan bahwa sikap yang positif yang dibentuk konsumen terhadap informasi E-WOM di media sosial memiliki efek positif pada niat pembelian.

H4: Brand attitude memdiasi eWOM terhadap purchase intention

Menurutu Indrawati (2015) kerangka pemikiran adalah menggali variabel-variabel yang terdapat pada penelitian sebelumnya dan variabel yang terkait dengan masalah dalam penelitian tersebut. Model kerangka pemikiran dalam penelitian ini merupakah adopsi dari Kumar (2017). Kumar (2017) mengatakan bahwa model kerangka pemikiran membentuk hubungan antara variabel independent yaitu electronic word of mouth, dan variabel dependent yaitu purchase intention dengan adanya variable mediator/intervening yaitu brand attitude. Maka dapat digambarkan sebuah kerangka pemikiran dari penelitian ini adalah sebagai berikut.

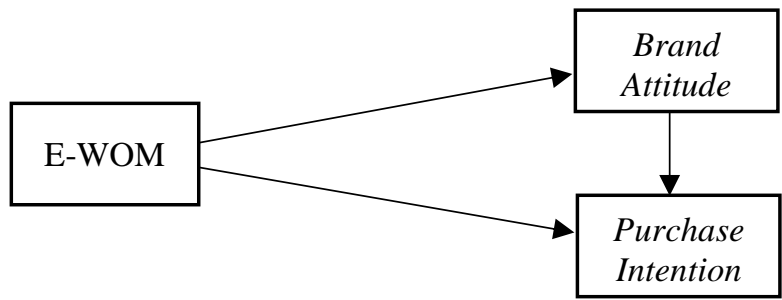

Gambar 5.

Sumber: Kumar (2017)

Kerangka Pemikiran

\section{METODE PENELITIAN}

Tabel 2.

Operasional Variabel

\begin{tabular}{|c|c|c|}
\hline Variabel & Indikator & No Item \\
\hline \multirow{4}{*}{$\begin{array}{l}\text { E-wom } \\
\text { (Bambauer-Sachse and Mangold, } \\
\text { 2011; Jalilvand and Samiei, 2012) }\end{array}$} & $\begin{array}{l}\text { Saya sering menonton atau membaca ulasan konsumen } \\
\text { atau teman lain tentang produk smartphone Samsung di } \\
\text { Youtube untuk memastikan saya membeli produk yang } \\
\text { benar. }\end{array}$ & 1 \\
\hline & $\begin{array}{l}\text { Saya sering menonton atau membaca ulasan dari } \\
\text { konsumen atau teman lain tentang produk smartphone } \\
\text { Samsung di Youtube untuk mengetahui produk tersebut } \\
\text { memberi kesan yang baik pada orang lain. }\end{array}$ & 2 \\
\hline & $\begin{array}{l}\text { Saya sering menonton atau membaca ulasan dari } \\
\text { konsumen atau teman lain tentang produk smartphone } \\
\text { Samsung di Youtube untuk mengumpulkan informasi } \\
\text { sebuah produk. }\end{array}$ & 3 \\
\hline & $\begin{array}{l}\text { Saya sering menonton atau membaca ulasan konsumen } \\
\text { atau teman lain tentang produk smartphone Samsung di } \\
\text { Youtube agar yakin dengan keputusan pembelian saya }\end{array}$ & 4 \\
\hline \multirow{4}{*}{$\begin{array}{l}\text { Brand Attitude } \\
\text { (Schivinski and Dabrowski, 2014; } \\
\text { Tang and Xiao, 2011.). }\end{array}$} & $\begin{array}{l}\text { Saya punya ide bagus tentang merek ini / saya tertarik } \\
\text { dengan produk brand smartphone Samsung }\end{array}$ & 5 \\
\hline & Produk brand Samsung memiliki reputasi yang baik & 6 \\
\hline & Saya lebih menyukai produk smarphone brand Samsung & 7 \\
\hline & $\begin{array}{l}\text { Smartphone brand Samsung merupakan produk yang } \\
\text { layak untuk dibeli }\end{array}$ & 8 \\
\hline \multirow{3}{*}{$\begin{array}{l}\text { Purchase intention } \\
\text { (Schivinski and Dabrowski, 2014; } \\
\text { Yoo et al., 2000;Shukla, 2011) }\end{array}$} & Saya akan membeli produk smartphone Samsung & 9 \\
\hline & $\begin{array}{l}\text { Saya akan membeli produk smartphone Samsung } \\
\text { daripada produk lain yang tersedia. }\end{array}$ & 10 \\
\hline & $\begin{array}{l}\text { Saya juga berniat membeli produk smartphone } \\
\text { Samsung di masa mendatang. }\end{array}$ & 11 \\
\hline
\end{tabular}

Sumber: Data Olahan Penulis (2020)

Pengaruh E-WOM di Media Sosial Youtube Terhadap Purchase Intention (Minat Beli) Pada Brand Smartphone 
Pada Tabel 2, berisikan indikator-indikator dari setiap variabel dalam penelitian. Indikatorindikator pada setiap variabel dalam penelitian ini merupakan hasil adopsi dari penelitian sebelumnya yang dilakukan oleh Kumar (2017). Untuk penelitian ini, skala pengukuran yang digunakan yaitu skala Likert. Menurut Sugiyono (2019) skala Likert digunakan untuk mengukur sikap, pendapat, dan persepsi seseorang atau kelompok orang tentang fenomena sosial. Berdasarkan tipe penelitian, penelitian ini termasuk tipe kausal.

Berdasarkan unit analisis penelitian yaitu bersifat individu. Penelitian ini berdasarkan keterlibatan peneliti bersifat non contrived setting yaitu bahwa penelitian dilakukan dengan tanpa keterlibatan dalam aktivitas alamiah subjek penelitian (Uma Sekaran, 2003) dalam Indrawati (2015). Berdasarkan waktu pelaksanaan, penelitian ini termasuk cross sectional adalah pengumpulan data dilakukan dalam satu periode, kemudian data itu diolah, dianalisis, dan kemudian ditarik kesimpulan Indrawati (2015).

Pada penelitian ini populasi yang digunakan pada penelitian ini adalah pengguna smartphone di Bandung yang menggunakan media sosial Youtube. Bandung menjadi tempat penelitian karena Menurut Effendi (2019) Bandung masih menjadi pasar yang menggiurkan bagi penjualan smartphone. Berbagai produk smartphone terus berlomba menjaring konsumen, utamanya kaum milenial yang begitu mudah tergoda jika ada keluaran terbaru (Effendi, 2019). Menurut Sugiyono (2019) bila jumlah populasi dalam penelitian tidak diketahui secara pasti jumlahnya, maka perhitungan jumlah sampel dapat menggunakan rumus Cochran. Maka pada penelitian ini, jumlah minimal sampel yang harus diambil adalah 385 responden. Jumlah ini merupakan jumlah minimal responden yang dibutuhkan dalam penelitian. Pada penelitian ini, teknik sampling yang digunakan yaitu teknik non probability sampling. Penelitian ini menggunakan pengujian instrument penelitian dengan uji validitas dan reliabilitas. Teknik analisis dalam pemenelitian ini yaitu teknik analisis deskriptif, teknik multivarian, Method of Successive Interval (MSI), Structural Equation Modeling (SEM), Uji normalitas, Uji Goodness-of-Fit, Uji Hipotesis.

\section{HASIL DAN PEMBAHASAN}

Dalam penelitian ini, tahap awal yang dilakukan sebelum melakukan pengolahan data, harus dilakukan pengujian dahulu apakah ada atau tidaknya outlier dan distribusi data harus normal secara multivariate.

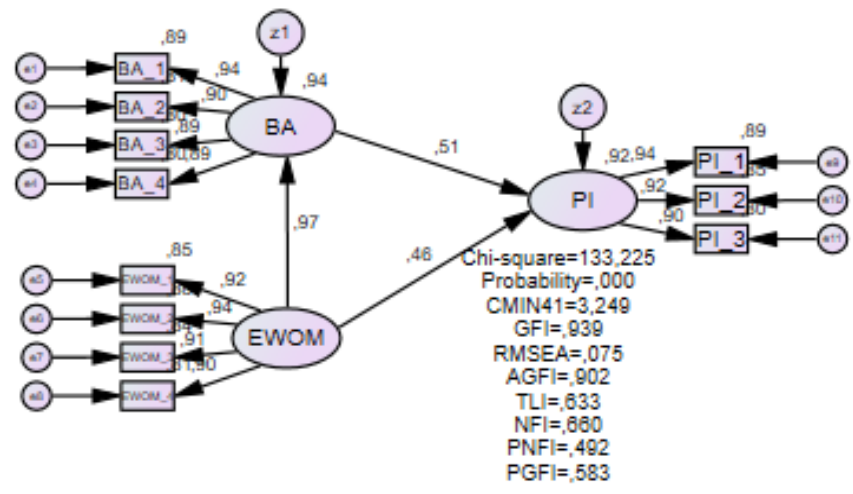

Gambar 6.

Hasil Pengolahan Data dengan Software AMOS 24

Sumber: Data diolah Penulis (2021)

Pada Gambar 6, software AMOS 24 perlu mengestimasi varians dank ovarian yang ada pada model penelitian yang telah dibuat. Model penelitian yang sudah di uji disajikan, hasil pengujian model menunjukan hasil perhitungan dari degree of freedom $(d f)$.

Pengaruh E-WOM di Media Sosial Youtube Terhadap Purchase Intention (Minat Beli) Pada Brand Smartphone Samsung, 
Tabel 3.

Computation of Degree of Freedom

\begin{tabular}{lc}
\hline Number of distinct sample moments. & $\mathbf{6 6}$ \\
\hline Number of distinct parameters to be estimated & 25 \\
Degrees of freedom $(66-25)$ & 41 \\
& Minimum was achived \\
Chi-square & 166,938 \\
Degrees of freedom & 41 \\
Probability level & 0 \\
\hline
\end{tabular}

Sumber: Data diolah Penulis (2021)

Dari Tabel 3, dapat dilihat bahwa penelitian ini memiliki model yang overidentified. Menurut Ghozali (2017) model overidentified adalah sebuah model yang memiliki jumlah parameter estimasi lebih kecil daripada jumlah data varian dan kovariannya sehingga degree of freedom yang dihasilkan positif.

Tabel 4.

Kriteria dan Hasil Model Goodness-Fit

\begin{tabular}{ccccc}
\hline Fit Category & $\begin{array}{c}\text { Goodness of Fit } \\
\text { Indices }\end{array}$ & Cutt of value & Hasil Model & Keterangan \\
\hline Absolute Fit & RMSEA & $0.05 \leq$ RMSEA $\leq 0,08$ & 0,088 & $f i t$ \\
& CMIN/DF & CMIN/DF $\leq 5,00$ & 4,073 & fit \\
& GFI & $0,90 \leq \mathrm{GFI}<1,00$ & 0,929 & fit \\
Incremental Fit & AGFI & $0,90 \leq \mathrm{AGFI}<1,00$ & 0,885 & Marginal \\
Parsimonious Fit & PNFI & $0<\mathrm{PNFI}<1$ & 0,707 & fit \\
& PGFI & $0<\mathrm{PGFI}<1,00$ & 0,577 & $\mathrm{fit}$ \\
\hline
\end{tabular}

Sumber: Data diolah Penulis (2021)

Setelah melakukan measurement model tahap selanjutnya ialah melakukan pengujian kecocokan model. Alat untuk pengujian ini dibagi menjadi tiga fit indices, yaitu absolute fit indices, incremental fit indices, dan parsimony fit indices, hal tersebut sesuai dengan pernyataan yang disampaikan oleh Hair et al. (2011) bahwa Confirmatory Factor Analysis (CFA) diperlukan setidaknya satu dari masing-masing alat uji yang sesuai dengan persyaratan indeksnya.

Hasil perhitungan uji goodness fit bahwa setiap jenis ukurannya menghasilkan data yang fit. Menurut Ghozali (2017) Uji Goodness-Fit digunakan untuk mengukur kesesuaian input observasi dengan prediksi dari model yang diajukan. Terdapat 3 jenis ukuran goodness-fit yaitu absolute fit measure, incremental fit measure, dan parsimonious measure.

Absolute fit measure digunakan untuk mengukur model fit secara keseluruhan dan terdapat goofness of fit indices yaitu RMSEA, CMIN/DF, dan GFI. Pada Incremental fit digunakan untuk membandingkan proposed model dengan model lainnya dan terhadapat goofness of fit yaitu AGFI, TLI dan NFI. Pada Parsomonious fit digunakan untuk membandingkan model dengan jumlah koefisien yang berbeda dan terdapat goofness of fit yaitu PNFI, dan PGFI.

Alat ukur CMIN/DF adalah nilai Chi-square dibagi dengan degree of freedom. Beberapa pengarang menganjurkan menggunakan ratio ukuran ini untuk mengukur fit. Menurut Wheaton rt. Al (1977) nilai ratio 5 (lima) atau kurang dari lima merupakan ukuran yang reasonable, pada penelitian ini nilai CMIN/DF yaitu 4,073 yang berarti nilai dikatakan fit karena masih dibawah lima. Untuk alat ukur RMSEA digunakan untuk menguji model konfirmatori strategi dengan jumlah sampel besar dan menurut Brown dan Cudeck (1993) $0.05 \leq$ RMSEA $<0,08$ menunjukkan good fit. Pada penelitian ini, nilai RMSEA yang didapat yaitu 0.088 yang masih kurang dari 0.08 . Selanjutnya, untuk nilai GFI dikembangkan oleh Joreskog dan Sorbom (1984) yaitu ukuran non statistic yang nilainya berkisar dari nilai 0 (poor fit) sampai 1.0 (perfect fit) dan nilai GFI yang tinggi menunjukkan fit yang lebih baik

Pengaruh E-WOM di Media Sosial Youtube Terhadap Purchase Intention (Minat Beli) Pada Brand Smartphone Samsung, 
(Ghozali, 2017). Pada hasil pengolahan data pada penelitian ini, nilai GFI yang didapat yaitu 0.929 dapat dikatakan fit.

Alat ukur AGFI menurut Ghozali (2017) merupakan pengembangan dari GFI yang disesuaikan dengan rating degree of freedom untuk proposed model dengan degree of freedom untuk null model. Nilai yang direkomendasikan adalah sama atau >0.90. Pada penelitian ini, nilai AGFI yaitu 0,885 dapat dikatakan fit. Untuk nilai TLI nilai yang direkomendasikan yaitu berkisar 0 sampai 1.0 dan pada penelitian ini nilai TLI yaitu 0.947 dan dapat dikatakan fit. Dan alat ukur NFI yaitu nilai perbandingan antaraproposed model dan null model (Ghozali, 2017) nilai yang direkomendasikan sama atau $>0.90$. Pada hasil pengolahan data didapat nilai NFI yaitu 0.948 dapat dikatakan fit.

Nilai PNFI menurut Ghozali (2017:66) dikatakan semakin tinggi nilai PNFI maka semakin baik. PNFI merupakan modifikasi dari NFI, yang digunakan untuk membandingkan model alternative dimana menjadikan PNFI tidak memiliki nilai fit yang menyatakan. Pada alat ukur PGFI, nilai dikatakan fit jika berkisar antara 0 sampai 1.0 dengan nilai semakin tinggi menunjukkan model lebih parsimony. Pada hasil pengolahan data ini, nilai PGFI yang didapat yaitu sebesar 0.577 yang dapat dikatakan fit.

Menurut Sugiyono (2017), hipotesis merupakan jawaban sementara dari rumusan masalah penelitian yang harus diuji kebenarannya berdasarkan data populasi dari sampel penelitian. Setelah melakukan tahap-tahap sebelumnya seperti uji validitas, uji reliabilitas, uji normalitas, uji measurement model, dan uji goodness-fit, tahap selanjutnya yang dilakukan oleh penulis ialah melakukan pengujian hipotesis menggunakan Structural Equation Model (SEM) dengan bantuan software AMOS 24. Menurut Wijayanto (2008) menyampaikan bahwa hubungan kausal yang dinyatakan tidak signifikan jika Critical Ratio $(C . R)$ yang identik dengan nilai T hitung memiliki nilai dibawah 1,96. Selain itu, untuk mempermudah dalam pengambilan suatu keputusan dapat dilihat dari angka probability $(\mathrm{P})$ jika $\mathrm{P}<0,05$ maka $\mathrm{H} 1$ menyatakan dan $\mathrm{H} 0$ tidak menyatakan (Santoso, 2018:169).

Hasil dari pengujian hipotesis dengan software AMOS 24 yang menunjukkan nilai Critical Ratio $(C . R)$ dan probability $(P)$ dapat disimpulkan bahwa hipotesis kesatu $(\mathrm{H} 1)$ terbukti dengan nilai 29,079, hipotesis kedua (H2) dengan nilai 3,699, dan hipotesis ketiga (H3) dengan nilai 3,337 pada penelitian ini secara keseluruhan ialah terbukti karena hasil dari critical ratio semua diatas 1.96 dan nilai probability $(P)<0.05$.

Tabel 5.

Hasil Uji Hipotesis melalui Nilai Critical Ratio dan Probabilitas

\begin{tabular}{lccccc}
\hline \multicolumn{1}{c}{ Variabel } & Estimate & SE & $\begin{array}{c}\text { Critical Ratio } \\
(\boldsymbol{C . R})\end{array}$ & Probabilitas & Keterangan \\
\hline $\begin{array}{l}\text { E-WOM } \rightarrow \text { Brand Attitude } \\
\begin{array}{l}\text { E-WOM } \\
\rightarrow \text { Purchase intention }\end{array}\end{array}$ & 1.007 & 0.062 & 16,333 & 0,000 & H1 terbukti \\
$\begin{array}{l}\text { Brand Attitude } \\
\rightarrow \text { Purchase intention }\end{array}$ & 0.168 & 0.154 & 1,086 & 0,277 & $\begin{array}{c}\text { H2 tidak } \\
\text { terbukti }\end{array}$ \\
\hline
\end{tabular}

Sumber: Data diolah Penulis (2021)

Berdasarkan Critical Ratio (C.R) untuk pengaruh eWOM terhadap Brand Attitude yaitu 16,333 lebih besar dibandingkan dengan nilai C.R sebesar 1,96, selain itu angka probability (P) pada hipotesis kesatu menghasilkan nilai $\mathrm{P}<0,05$ ditunjukkan dengan nilai 0,000 sehingga $\mathrm{H} 1$ terbukti yang berarti signifikan memiliki hubungan. Dengan terbuktiya hipotesis kedua (H1) hal ini dapat diartikan bahwa eWOM berpengaruh secara signifikan terhadap Brand Attiude pada Purchase intention smartphone Samsung di Bandung pada media sosial Youtube.

Berdasarkan Critical Ratio (C.R) untuk pengaruh eWOM terhadap Purchase intention yaitu 1,086 lebih kecil dibandingkan dengan nilai C.R sebesar 1,96, selain itu angka probability (P) pada hipotesis kesatu menghasilkan nilai $\mathrm{P}<0,05$ ditunjukkan dengan nilai 0,277 sehingga $\mathrm{H} 2$ tidak menyatakan, yang berarti tidak signifikan memiliki hubungan. Dengan tidak menyatakannya hipotesis

Pengaruh E-WOM di Media Sosial Youtube Terhadap Purchase Intention (Minat Beli) Pada Brand Smartphone Samsung, 
kesatu (H2) hal ini dapat diartikan bahwa eWOM tidak berpengaruh secara signifikan terhadap Purchase intention pada media sosial Youtube.

Berdasarkan Critical Ratio (C.R) untuk pengaruh Brand Attitude terhadap Purchase intention yaitu 5,395 lebih besar dibandingkan dengan nilai C.R sebesar 1,96, selain itu angka probability $(\mathrm{P})$ pada hipotesis kesatu menghasilkan nilai $\mathrm{P}<0,05$ ditunjukkan dengan nilai 0,000 sehingga H3 terbukti, yang berarti signifikan memiliki hubungan. Dengan terbuktinya hipotesis ketiga (H3) hal ini dapat diartikan bahwa Brand Attitude berpengaruh secara signifikan terhadap Purchase intention smartphone Samsung di Bandung pada media sosial Youtube.

Berdasarkan hasil pengolahan data yang telah dilakukan sebelumnya, maka diperoleh hasil uji hipotesis dalam penelitian yang ditampilkan pada Tabel 5 , bahwa uji hipotesis, terlihat bahwa variabel laten independen dalam penelitian memiliki hubungan positif dan signifikan terhadap variabel laten dependen dan variabel mediator/intervening Dengan terbuktinya hipotesis keempat (H4) hal ini dapat diartikan bahwa Brand Attitude memediasi sempurna dikarenakan pengaruh eWOM pada Purchase intention smartphone samsung di Bandung pada media sosial Youtube baru terjadi ketika brand attitude memediasi pengaruh tersebut. Didapat hasil dari hipotesis yang telah diajukan bahwa hasil hipotesis terbukti atau dapat dikatakan semua hasil signifikan sedangkan satu hipotesis tidak berpengaruh secara signifikan yaitu eWOM berpengaruh signifikan terhadap Brand Attitude, eWOM tidak berpengaruh signifikan terhadap Purchase intention, Brand Attitude berpengaruh signifikan terhadap Purchase intention, dan Brand attitude memediasi sempurna pengaruh eWOM terhadap purchase intention.

Pada penelitian ini, dijelaskan pengaruh eWOM terhadap Purchase intention. Hasil tersebut diperoleh menggunakan analisis SEM, melalui software AMOS 24. Diperoleh hasil yaitu nilai CR yang didapat $1,086>1,96$ dan nilai $p$ yaitu $0,277<0.005$. Hal ini membuktikan komunikasi antar audiens pada media sosial Youtube terhadap smartphone Samsung kurang menimbulkan pengaruh terhadap minat pembelian konsumen khususnya di Kota Bandung.

Qian \& Guo (2012) menjelaskan beberapa karakteristik dari EWOM salah satunya adalah anonimitas. Anonimitas atau tidak diketahuinya siapa pengirim pesan EWOM membuat konsumen meragukan kredibilitas pesan yang diberikan oleh orang yang tidak dikenal atau anonim tersebut. Kania (2013) juga menemukan bahwa EWOM memang berpengaruh terhadap minat beli akan tetapi pengaruh yang dihasilkan sangatlah kecil yakni hanya $20,9 \%$.

Berbeda dengan hasil penelitian yang dilakukan (Imbayani \& Gama, 2018) mengatakan bahwa review yang lebih baik dari seseorang dari internet menghasilkan minat beli yang tinggi. Hal ini dikarenakan konsumen telah melihat dan membaca berbagai informasi yang disampaikan oleh konsumen lain yang kemudian diberitakan melalui blog atau web terpercaya.

Hal ini berbeda dengan EWOM yang informasinya diberikan oleh orang lain yang tidak terkait dengan perusahaan. Promosi melalui media sosial memang langsung disampaikan oleh pihak perusahaan Samsung itu sendiri. Hal itulah yang memperkuat dugaan peneliti bahwa kredibilitas pesan dari EWOM masih diragukan sehingga konsumen cenderung memilih Sumber yang lebih akurat yakni situs perusahaan itu sendiri maupun promosi langsung yang diberikan oleh perusahaan smartphone brand Samsung di masa yang akan datang.

Pada penelitian ini, akan dijelaskan pengaruh eWOM terhadap Brand Attitude. Hasil tersebut diperoleh menggunakan analisis SEM, melalui software AMOS 24. Diperoleh hasil yaitu nilai CR yang didapat 29,079 > 1,96 dan nilai p yaitu 0,000 < 0.005. Hal ini membuktikan bahwa semakin baik ewom smartphone Samsung di media sosial Youtube, maka akan dapat memberikan dan menciptakan sikap merek konsumen terhadap smartphone samsung dimasa yang akan datang.

Sejalan dengan hasil penelitian yang dilakukan Park \& Jeon (2018), menyelidiki bahwa pengaruh electronic word of mouth pada konsumen western (AS) dan hasil electronic word of mouth berpengaruh langsung terhadap perubahan brand attitude di western (US) kelompok yang mempunyai gaya berpikir analitis terhadap suatu merek, dimana eksposur eWOM yang kredibel dan memiliki kualitas tertentu mampu mengubah niat sikap merek konsumen menjadi positif.

Pada penelitian yang dilakukan oleh (Heryana \& Yasa, 2020) electronic word of mouth berpengaruh terhadap brand attitude karena semakin banyak review word of mouth secara online atau elektronik pada akun media sosial untuk bisnis maka semakin kuat atau meningkatkan brand attitude

Pengaruh E-WOM di Media Sosial Youtube Terhadap Purchase Intention (Minat Beli) Pada Brand Smartphone Samsung, 
pembeli atau pengguna merek tersebut. Hal ini membuktikan bahwa semakin baik eWOM di media sosial Youtube mengenai smartphone Samsung maka akan semakin baik persepsi konsumen dan memberikan sikap terhadap merek konsumen ke smartphone Samsung akan lebih baik di masa yang akan datang.

Pada penelitian ini, akan dijelaskan pengaruh Brand Attitude terhadap Purchase intention. Hasil tersebut diperoleh menggunakan analisis SEM, melalui software AMOS 24. Diperoleh hasil yaitu nilai CR yang didapat $3.337>1,96$ dan nilai p yaitu $0,000<0.005$. Sejalan dengan hasil penelitian yang dilakukan Taute \& Sierra (2014) yang meneliti pembelian merek smartphone. Hasil penelitian menunjukkan bahwa semakin tinggi sikap merek konsumen maka semakin tinggi pula niat pembelian kembali dimana sikap tersebut terbentuk dari periklanan dan juga promosi merek. Hasil serupa juga ditemukan dalam temuan (Lee et al., 2017) bahwa sikap merek berpengaruh positif terhadap niat membeli kembali. Hasil penelitian menemukan bahwa perilaku membeli diubah oleh sikap merek. Fakta bahwa sikap merek merupakan parameter penyebab yang mempengaruhi niat membeli kembali (Heryana \& Yasa, 2020).

Sikap konsumen terhadap merek memiliki pengaruh penting terhadap niat beli, karena sikap merek merupakan determinan terpenting dari niat beli (Abzari dan Vosta, 2014). Hal ini membuktikan bahwa semakin baik Brand Attitude konsumen terhadap smartphone Samsung maka akan semakin baik dan minat beli konsumen terhadap smartphone Bandung akan meningkat di masa yang akan dating.

\section{SIMPULAN DAN SARAN}

Berdasarkan dari penelitian bahwa variabel dengan tanggapan yang paling tinggi yaitu variabel eWOM. eWOM smartphone Samsung memiliki pengaruh yang signifikan terhadap brand attitude pada media sosial Youtube terhadap smartphone Samsung di Bandung. Berdasarkan hasil pengujian hipotesis, bahwa eWOM smartphone Samsung tidak memiliki pengaruh yang signifikan terhadap Purchase intention pada media sosial Youtube terhadap smartphone Samsung di Bandung. Berdasarkan hasil pengujian hipotesis diketahui, bahwa brand attitude berpengaruh secara signifikan terhadap purchase intention smartphone Samsung di Bandung pada media sosial Youtube. Secara keseluruhan bahwa variabel eWOM dapat mempengaruhi brand attitude namun tidak dapat mempengaruhi variabel purchase intention, dimana brand attitude menjadi variabel mediator/intervening yang memiliki pengaruh signifikan.

Berdasarkan hasil penelitian yang telah dilakukan menunjukkan bahwa eWOM secara signifikan mempengaruhi brand attitude dan purchase intention smartphone Samsung di media sosial Youtube, dari hasil tersebut saran yang dapat diberikan kepada pihak perusahaan ialah sebagai berikut: Bagi perusahan Samsung diharapkan bisa menciptakan rasa yakin, persepsi konsumen dan menumbuhkan kepercayaan untuk menciptakan sikap terhadap merek konsumen karena dari evaluasi brand tersebut merupakan salah satu penilaian baik buruknya suatu perusahaan yang dapat mengatakan sikap merek yang tercipta dari konsumen dan akan disebarkan melalui eWOM dan akan mempengaruhi sikap terhadap merek mereka. Berdasarkan hasil analisis yang telah dilakukan, bahwa variabel eWOM memiliki pengaruh sangat baik. Maka Samsung dapat memanfaatkan eWOM yang tinggi dengan cara lebih memberikan konten pada akun Youtube Samsung Indonesia dan Manajemen dari Samsung harus lebih meningkatkan kembali kepercayaan di benak konsumen dan harus bertindak dengan tanggap pada pemberitaan yang buruk apabila terjadi kesalahan pada produk ataupun mendapatkan komentar negative pada media sosial Youtube yang dapat memberikan kerugian bagi konsumen. Salah satunya dapat dilakukan dengan memberikan berupa kompensasi pada konsumen dan menerima masukan dan lebih memperhatikan eWOM yang tersebar. Membuat konten yang informatif dan menarik sehingga mengundang audiens untuk melakukan feedback berupa komentar pada konten tersebut contohnya konten mengenai konten promo untuk smartphone Samsung, dan menciptakan \#hastag yang dapat mengambil perhatian audiens. Berdasarkan analisis yang telah dilakukan, bahwa item "saya punya ide bagus tentang merek atau saya tertarik dengan produk smartphone brand Samsung" pada variabel Brand Attitude memiliki nilai tanggapan responden yang

Pengaruh E-WOM di Media Sosial Youtube Terhadap Purchase Intention (Minat Beli) Pada Brand Smartphone Samsung, 
rendah. Oleh karena itu, untuk meningkatkan ide dan daya tarik produk, Samsung harus melakukan kolaborasi dengan brand yang memiliki daya tarik rasional ataupun emosial agar mencakup jangkauan pasar yang lebih luas dan memunculkan sikap terhadap merek yang kuat.

Berdasarkan hasil penelitian, penulis memiliki keterbatasan yang dapat dijadikan sebagai saran bagi peneliti selanjutnya. Pada penelitian selanjutnya dapat melakukan penelitian serupa, tetapi dengan menggunakan platform yang berbeda misalnya Facebook, Twitter, atau media sosial yang lainnya sehingga dapat melihat kemungkinan hasil yang berbeda. Penelitian selanjutnya juga dapat membahas eWOM negative dan eWOM positif secara terpisah, hal tersebut akan mengungkapkan perbandingan antara hasil atau pengaruh eWOM yang bersifat positif dan negative jika ada perbedaan. Lalu peneliti selanjutnya dapat menggunakan objek penelitian lain selain produk smartphone.

\section{REFERENSI}

Abzari, M., Ghassemi, R. A., \& Vosta, L. N. (2014). Analysing the Effect of Social Media on Brand Attitude and Purchase Intention: The Case of Iran Khodro Company. Procedia - Social and Behavioral Sciences, 143, 822-826. https://doi.org/https://doi.org/10.1016/j.sbspro.2014.07.483

Appel, G., Grewal, L., Hadi, R., \& Stephen, A. T. (2020). The future of social media in marketing. Journal of the Academy of Marketing Science, 48(1), 79-95. https://doi.org/10.1007/s11747-019-00695-1

Billfakkar, M. F., \& Widyastuti, D. A. (2016). Perilaku Konsumen Smartphone Xiaomi Redmi 1S Di Jakarta. 295-319.

Erkan, I., \& Evans, C. (2016). The influence of eWOM in social media on consumers purchase intentions: an extended approach to information adoption. Computers in Human Behavior, 61(11), 47-55.

Goldsmith, R. E., \& Horowitz, D. (2006). Measuring Motivations for Online Opinion Seeking. Journal of Interactive Advertising, 6(2), 2-14. https://doi.org/10.1080/15252019.2006.10722114

Gruen, T., Osmonbekov, T., Gruen, T. W., \& Czaplewski, A. J. (2006). eWOM: The impact of customer-tocustomer online know-how exchange on customer value and loyalty. Article in Journal of Business Research. https://doi.org/10.1016/j.jbusres.2005.10.004

Harrie, L., Rahmat, H., \& Leni, C. (2017). An Investigation Of Implementation Samsung Promotion On Media (Youtube, Twitter And FAacebook) For Purchasing Decision. Evolving Trends in Social Sciences and Business Studies (ETSBS), Bali, Indonesia 23 March 2017 ISBN : 979-53-7829-7 AN.

Hennig-Thurau, T. (2014). Electronic Word of Mouth: Motives for and Consequences of Reading Customer Articulations on the Internet Entertainment Science View project Success Factors of Cultural Products View project. Elsevier. https://doi.org/10.1002/dir.10073

Heryana, D. K., \& Yasa, N. N. K. (2020). Effect of electronic word of mouth on repurchase intention mediated by brand attitude. International Research Journal of Management, IT and Social Sciences, 7(2), 9-20. https://doi.org/10.21744/irjmis.v7n2.854

Imbayani, I., \& Gama, A. (2018). The Influence of Electronic Word of Mouth (E-Wom), Brand Image. Product Knowledge on Purchase Intention Jurnal Ekonomi Dan Bisnis Jagaditha, 5(2), 145. https://doi.org/10.22225/jj.5.2.813.145-153

Ismagilova, E., Dwivedi, Y. K., Slade, E., \& William, M. D. (2017). Word, Electronic (eWOM), of Mouth Marketing, in the Context Art, A State of the Future, Analysis andWord, Electronic (eWOM), of Mouth Marketing, in the Context Art, A State of the Future, Analysis and Directions Directions. Springer briefs in Business.

Jalilvand, M. R., \& Samiei, N. (2012). The effect of electronic word of mouth on brand image and purchase intention: An empirical study in the automobile industry in Iran. Marketing Intelligence and Planning, 30(4), 460-476. https://doi.org/10.1108/02634501211231946

Jalilvand, M. R., Samiei, N., Behrooz, D., \& Manzari, P. Y. (2012). Examining the structural relationships of electronic word of mouth, destination image, tourist attitude toward destination and travel intention: An integrated approach. Journal of Destination Marketing and Management, 1(1-2), 134-143. https://doi.org/10.1016/j.jdmm.2012.10.001

Keller, K.L. and Lehmann, D.R. 2006. Brands and branding: research findings and future priorities. Marketing Science, Vol. 25 No. 6, pp. 740-757.

Khalisha, G., Rachmadini, N., \& K, K. F. (2019). Pengaruh Iklan Online Naratif Move on Trip terhadap Sikap Penonton Media Sosial Youtube. Jurnal Ilmu Komunikasi Dan Humaniora, 1(2), 90-96. https://doi.org/https://doi.org/10.32509/jhm.v1i2.831

Kumar, C. K. A. (2017). Social eWOM: Does it Affect the Brand Attitude and Purchase Intention of Brands?

Pengaruh E-WOM di Media Sosial Youtube Terhadap Purchase Intention (Minat Beli) Pada Brand Smartphone 
Management Research Review, 40(3). https://doi.org/http://dx.doi.org/10.1108/MRR-07-2015-0161

Kotler, P. \& Keller, K.L. (2012), Manajemen Pemasaran Jilid I Edisi ke 12. Jakarta: Erlangga

Lee, E. B., Lee, S. G., \& Yang, C. G. (2017). The influences of advertisement attitude and brand attitude on purchase intention of smartphone advertising. Industrial Management and Data Systems, 117(6), 10111036. https://doi.org/10.1108/IMDS-06-2016-0229

Mitchell, A. A., \& Olson, J. C. (1981). Are Product Attribute Beliefs the Only Mediator of Advertising Effects on Brand Attitude? Journal of Marketing Research, 18(3), 318-332. https://doi.org/10.1177/002224378101800306

Olsen, M. C., Slotegraaf, R. J., \& Chandukala, S. R. (2014). Green claims and message frames: How green new products change brand attitude. Journal of Marketing, 78(5), 119-137. https://doi.org/10.1509/jm.13.0387

Prendergast, G., Ko, D., \& Siu Yin, V. Y. (2010). Online word of mouth and consumer purchase intentions. International Journal of Advertising, 29(5), 687-708.

Sparks, B. A., \& Browning, V. (n.d.). The impact of online reviews on hotel booking intentions and perception of trust. Elsevier.

Spears, N., \& Singh, S. N. (2004). Measuring Attitude Toward the Brand and Purchase Intentions. In Journal of Current Issues and Research in Advertising (Vol. 26, Issue 2).

Sugiyono (2019). Statistika untuk Penelitian. Bandung : CV Alfabeta.

Tan, L., \& Keni. (2020). Prediksi E-Wom dan Subjective Norm terhadap Purchase Intention: Brand Attitude Sebagai Variabel Mediasi. Jurnal Manajerial Dan Kewirausahaan, 2(3), $765-774$. https://journal.untar.ac.id/index.php/JMDK/article/view/9590

Taute, H. A., \& Sierra, J. (2014). Brand tribalism: an anthropological perspective. The Journal of Product and Brand Management, 23(1), 2. http://dx.doi.org/10.1108/JPBM-06-2013-0340

Timpal, N., S.L.H.V.J, L., \& Rate, P. Van. (2016). Pengaruh brand awareness dan brand attitude terhadap keputusan pembelian handphone merek nokia (studi kasus pada siswa sma dan smk di kota manado). Jurnal Berkala Ilmiah Efisiensi, 16(01), 308-317.

Toufani, S. (2015). The importance of aesthetics on customers' intentions to purchase smartphones. Marketing Intelligence and Planning, 35(3), 316-338. https://doi.org/https://doi.org/10.1108/MIP-12-2015-0230

Top Brand Award. (2020). Top Brand Award Kategori Smartphone. https://www.topbrandaward.com/en/2019/05/smartphone-2/ [25 Oktober 2020]

Wahdian, \& Setiawati, S. D. (2020). Customer Relationship Management Pt. Samsung Electronics Indonesia Di Tengah Pandemi Covid-19 Di Indonesia. Linimasa: Jurnal Ilmu Komunikasi, 3(2), 55-66. https://doi.org/http://dx.doi.org/10.23969/linimasa.v3i2.2778.

Waluyo, Minto. 2016. Mudah Cepat Tepat Penggunaan Tools Amos dalam Aplikasi (SEM). Jawa Timur: Penerbit UPN "Veteran" Jawa Timur

Wheaton et.al. (1997). Assesing Reliability and Stability in Panel Model. In Heise, D.R. (Ed). Sociological Methodology 1977. San Fransisco: Jossey-Bass,DE.1937. The identification Problem in Structural Equation Model with Unmeasured Variabels. In A.S. Goldberger dan O.D. Duncan (Eds). Structutal Equation Models in The Social Sciences (Vols 69-83). New York: Academic Press.

Widodo. (2017). Metode Penelitian Populer \& Praktis. Jakarta: Raja Grafindo Persada

Wijanto, S. H. (2008). Structural Equation Modeling Dengan LISREL 8.8. Graha Ilmu.

Wu, P. C. S., \& Wang, Y.-C. (2011). The influences of electronic word-of-mouth message appeal and message source credibility on brand attitude. Emerald.Com, 23(4), 448-472. https://doi.org/10.1108/13555851111165020

Youtube. (2020). Samsung Indonesia. https://www.Youtube.com/user/samsungindonesia [12 November 2020].

Pengaruh E-WOM di Media Sosial Youtube Terhadap Purchase Intention (Minat Beli) Pada Brand Smartphone Samsung, 